\title{
一般口演 8
}

\section{下顎運動情報を用いた運動論的基準軸の空間的特徴の検討}

\section{Investigation of the spatial characteristic of the kinematic axes estimated} from mandibular movements

\author{
$\bigcirc$ 伊藤崇弘 ${ }^{1)}$, 重本修伺 ${ }^{1)}$, 井川知子 ${ }^{1)}$, 伊藤光彦 ${ }^{1)}$, 小川 ⿷匚 $^{1)}$, 松香芳三 ${ }^{2)}$ \\ Ito $\mathrm{T}^{1)}$, Shigemoto $\mathrm{S}^{1)}$, Ikawa $\mathrm{T}^{1)}$, Ito $\mathrm{M}^{1)}$, Ogawa $\mathrm{T}^{1)}$, Matsuka $\mathrm{Y}^{2)}$ \\ 1) 鶴見大学歯学部クラウンブリッジ補経学講座 \\ 2) 徳島大学大学院医歯薬学研究部顎機能咬合再建学分野 \\ ${ }^{1)}$ Department of Fixed Prosthodontics, Tsurumi University School of Dental Medicine \\ ${ }^{2)}$ Department of Stomatognathic Function and Occlusal Reconstruction, Institute of Biomedical Sciences, \\ Tokushima University Graduate School
}

\section{I. 目的}

顆頭間軸を用いて顎運動を表現する顎運動モデルとし て, 矢状面内のすべての運動に対する回転軸である全運 動軸 (Kinematic Axis：KA）が存在する。しかし, 顎 機能異常者は, 直線 (軸) として求められない場合があ る. 平井らは, 少数例ではあるが矢状面内において運動 範囲が最小となる軸（最小運動軸 Least Motion Axis： LMA）が，KA が求められない顎機能異常者において も算出が可能であることを報告している ${ }^{1)}$. 本研究では, 顎口腔機能健常者の矢状面限界運動から KA, LMA を 算出し, これらの空間的特徴について検討を行ったので 報告する。

\section{II. 方 法}

\section{1. 被験者}

顎口腔系の機能異常およびその既往がなく, 個性正常 咬合を有する成人有歯顎者 45 名（男性 24 名, 女性 21 名, $26.7 \pm 6.6$ 歳）を被験者とした。本研究は, 徳島大学病 院臨床研究倫理審査委員会（第575号）の承認を受け, 事前に研究の主旨を説明し, 同意を得た上で測定を行っ た.

\section{2. 顎運動測定}

磁気式 6 自由度顎運動測定器 ${ }^{2)}$ を用いて顎運動測定を 行った。被験運動を矢状面内限界運動とし, サンプリン グ周波数 $100 \mathrm{~Hz}$ で 3 回測定した. 上顎切歯点 (IN), 左

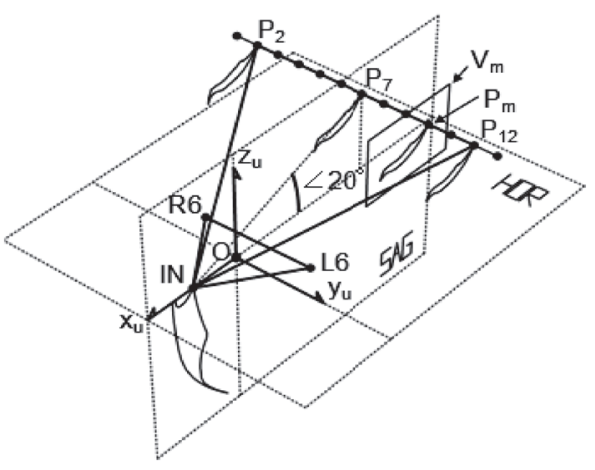

図 1 基準座標系および初期顆頭間軸

右第一大毁歯中心窩（L6，R6）で定義される上顎咬合 平面座標系 $\left(\mathrm{O}_{\mathrm{U}}-\mathrm{x}_{\mathrm{U}} \mathrm{y}_{\mathrm{U}} \mathrm{Z}_{\mathrm{U}}\right)$ を基準座標系とした（図 1$)$.

\section{3. 運動軸の探索方法}

Shigemoto $^{3)}$ の方法に準じて自動で KA，LMAを算出 した。まずBonwill 三角 $\left(\triangle \mathrm{IN}-\mathrm{P}_{2}-\mathrm{P}_{12}\right)$ の一辺を 100 $\mathrm{mm}$, Balkwill 角を $20^{\circ}$ と , 初期顆頭間軸（直線 $\mathrm{P}_{2}$ $\left.\mathrm{P}_{12}\right)$ 上に $10 \mathrm{~mm}$ 間隔で 13 点 $\left(\mathrm{P}_{1}-\mathrm{P}_{13}\right)$ を設定した（図 $1)$. それぞれの点をとおる矢状面 $\mathrm{V}_{\mathrm{m}}(\mathrm{m}=1-13)$ 内で 全運動軸点 $\mathrm{KA}_{\mathrm{m}}(\mathrm{m}=1-13)$ および最小運動軸点 $\mathrm{LMA}_{\mathrm{m}}$ $(m=1-13)$ を算出した. 求めた 13 個の各軸点の 3 次元 近似直線をそれぞれ KA およびLMA とした。

\section{4. 解析項目}

1 ）運動軸としての特徽

3 次元の線形性を評価するために近似直線の各軸点と の距離の RMS 值 (Drms) を算出した。次に, KA につ 


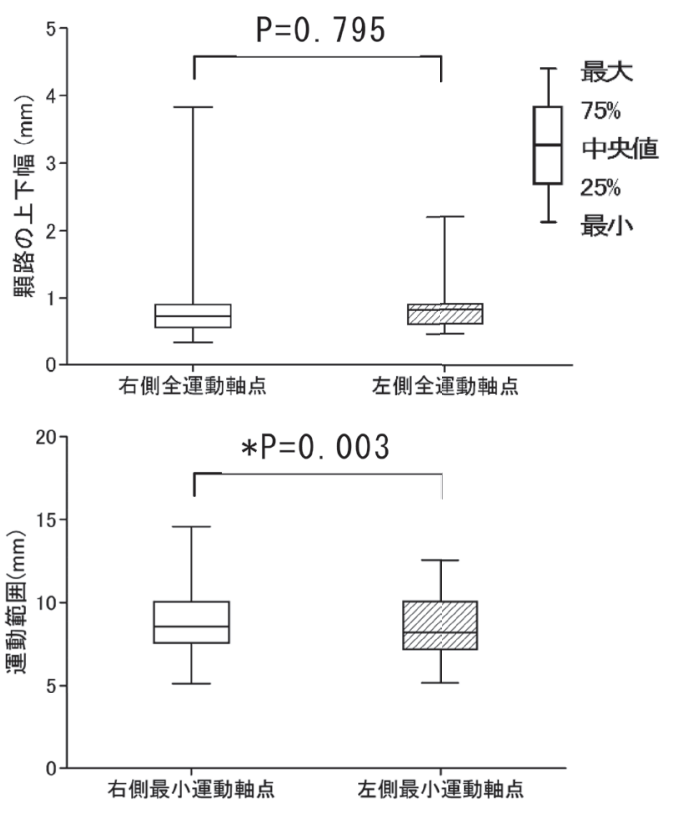

図 $2 \mathrm{KA}$ と LMA の左右差

いては，各軸点における顆路の上下幅を，LMA につい ては, 運動範囲（運動経路の平均位置からの距離の最大 値）を求めた。

2) KA と LMA の空間的位置関係

KA と LMA の平行性については 2 軸のなす角を, 距 離については求めた 13 点の座標值（前後 $\mathrm{X}$ 成分, 上下 - Z 成分）の平均值を, 各被験者の代表值として比較し た。

\section{5. 統計処理}

統計処理には, Wilcoxon signed-rank testを用い有意 水準 5 \%で群間比較を行った。

\section{III. 結果及び考察}

\section{1. 運動軸としての特徵}

KA, LMA の Drmsの中央值（最小-最大）は, そ れぞれ $0.085 \mathrm{~mm}(0.006-6.253 \mathrm{~mm}), 0.048 \mathrm{~mm}(0.009$ - $1.023 \mathrm{~mm}$ ) であり，両軸とも高い線形性を示した. LMA は KA より有意に高い線形性を示した $(\mathrm{P}=0.015)$.

KA の顆路の上下幅と LMA の運動範囲の左右差につ いて, 各軸上の点 KA2 と LMA2, KA12 と LMA12を各 被験者の左右側の代表値とし比較した結果, KA は有意 な差は認めなかった（P=0.795）。一方，LMA は有意な 差を認めた $(\mathrm{P}=0.003)$. しかし LMA は右側 $8.560 \mathrm{~mm}$, 左側 $8.202 \mathrm{~mm}$ と差が小さく左右差の絶対值は非常に小

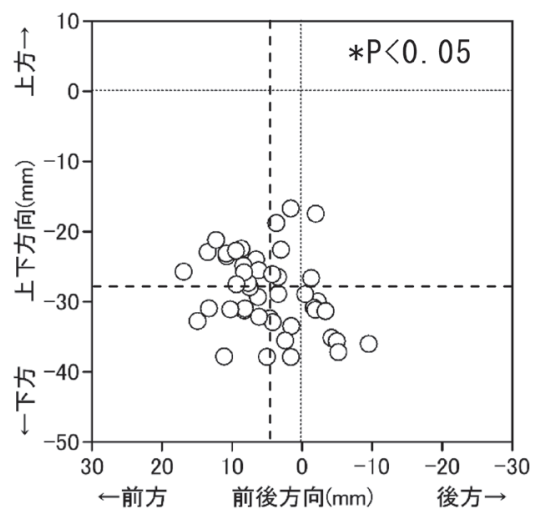

図 3 KA に対する LMA の空間的位置 $(0,0)$ は KA の位置を示す.

さいといえる(図 2).

$\mathrm{KA}_{\mathrm{m}}$ の顆路の上下幅および $\mathrm{LMA}_{\mathrm{m}}$ の運動範囲の平均 值を各被験者の代表値とすると 45 名の KA の上下幅は 平均 $0.872 \pm 0.491 \mathrm{~mm}, \mathrm{LMA}$ の運動範囲は平均 $8.66 \pm$ $1.77 \mathrm{~mm}$ であった。

\section{KA と LMA の空間的位置関係}

KA と LMA のなす角は, 平均 $2.742 \pm 2.970^{\circ}$ であり, KA と LMA はほぼ平行であることが示された。次に $\mathrm{KA}$ とLMAの空間的な位置関係について比較した結 果，LMA は KA に対して有意に前方 $(4.83 \mathrm{~mm})$ およ び下方（28.68 mm）に位置していた（P<0.05）（図 3 ).

以上より顎口腔機能健常者においては KA，LMAは ともに直線（軸）として算出でき，かつ各軸に運動論的 左右差はなく, LMA は KA に対しほぼ平行かつ前下方 に存在することが示唆された。

\section{N. 文献}

1) Hirai S, et al. : Relationship between the mandibular movements and deformation of the coronoid process and the condyle. J Jpn Assoc Oral Rehabil. 2016; (in press).

2 ) 石川輝明。三軸コイルを用いたチェアサイド用 6 自 由度澦運動測定器の開発と応用. 四国歯誌 2006 ; $19: 55-66$.

3 ) S Shigemoto, et al. : Effect of an exclusion range of jaw movement data from the intercuspal position on the estimation of the kinematic axis point. Medical Engineering and Physics 2014; 36(9): 1162-1167. 